\title{
Glycemic Index of Taro Stem Flour (Colocasia Esculenta) in Male White Rats
}

\author{
Yulianita, Mulyati Effendi, Tini Suryani
}

\begin{abstract}
Taro plants are food crops that have many benefits, including leaves, stems, and taro tubers. In $100 \mathrm{~g}$ of taro rods there are $20 \mathrm{mg}$ of phosphorus, $60 \mathrm{mg}$ of calcium, $400 \mathrm{mg}$ carbohydrate, $100 \mathrm{mg}$ of fiber and other minerals. This study aims to determine the value of glycemic index of taro stem flour (Colocasia esculenta) in male white rats. Test animals used were 10 rats given $0.9 \mathrm{~g} / 200 \mathrm{~g} \mathrm{BB}$ of pure glucose (food reference). For two hours of reference food consumption, blood samples were taken every 30 minutes to measure their glucose levels (measurement of glucose levels at $0,30^{\text {th }}, 60^{\text {th }}, 90^{\text {th }}$, and $120^{\text {th }}$ minutes). Interval of 3 days, done the same thing by giving 0.9 $\mathrm{g} / 200 \mathrm{~g} \mathrm{BB}$ of taro stem flour (as test food). The results showed that taro stem flour had a value of 95.895 glycemic index an included in high category (> 70). Foods that have high glycemic index values can be consumed by people with hypoglycemia and people who are not obese.
\end{abstract}

Index Terms: Taro plants, glycemic index, Test animals

\section{INTRODUCTION}

Along with the development of degenerative diseases, many methods of treatment are offered to people ranging from traditional medicine to modern methods of treatment. In addition to treatment, one way of managing problems degenerative disease is by setting food or diet that can be done through the selection of the right amount and type of carbohydrate using the concept of the Glycemic Index (GI).

The glycemic index (GI) of food is the level of food according to its effect on blood glucose levels with a range of $0-100$. Food that raises blood glucose levels quickly has a high GI, whereas low GI foods will increase blood glucose levels slowly [1].

According to Jenny Miller in Waspadji and Sukardji (2003), the glycemic index value is categorized into three groups, namely low GI food with a range of GI values $<55$, moderate GI food with a range of IG 55-70, and high IG food with IG values $>70$. The concept of the glycemic index is useful for everyone, foods that have a low glycemic index value are useful for people who suffer from hyperglycemia, while foods that have a high glycemic index value are useful for people suffering from hypoglycemia [2].

Revised Manuscript Received on April 25, 2019.

Yulianita, Department of Pharmacy, Faculty of Mathematic and Natural Science, Pakuan University, Bogor 16143

Mulyati Effendi, Department of Biology, Faculty of Mathematic and Natural Science, Pakuan University, Bogor 16143.

Tini Suryani, Department of Pharmacy, Faculty of Mathematic and Natural Science, Pakuan University, Bogor 16143
Hyperglycemia or diabetes mellitus is a degenerative disease whose prevalence continues to increase. Diabetes mellitus is defined as a disease or chronic metabolic disorder with multi etiology characterized by high blood sugar levels accompanied by metabolic disorders of carbohydrates, lipids and proteins as a result of insulin function insufficiency [3]. While hypoglycemia is a condition in which blood glucose levels are below normal, which is $<70 \mathrm{mg} / \mathrm{dL}$ [4].

Research on the analysis of the current food glycemic index has been widely carried out in various countries including Indonesia. However, the study of the glycemic index value of alternative local foods is a limited source of carbohydrates such as taro stems. Based on this, the researcher was interested in examining the glycemic index of taro stem flour (Colocasia esculenta) in male white rats as experimental animals.

\section{MATERIALS AND METHOD}

\section{A. Material}

Taro stems (Colocasia esculenta), adult male (Spargue Dawley) rats with a body weight of about 200-300 $\mathrm{g}$ as many as 10 tails, standard feed, aquadest, and glucose.

\section{B. Tool}

Sieve 100 mesh, crucible cup, furnace (Vulcan A-55®), Moisture Balance (AND MX-50®), oven, blender, hull sonde, blood sugar or glucometer (Easy Touch ${ }^{\circledR}$ ), scales, erlenmeyer, and other glassware.

\section{Methods}

\section{Material Collection and Plant Determination}

The material used in this study was taro stem, which was obtained from the Bogor Main Market, and was determined at the Indonesian Institute of Sciences (LIPI) Cibinong. J1. Raya Jakarta - Bogor KM. 46 Cibinong 16911.

\section{Making Taro Stem Flour}

Taro bar used as much as $5 \mathrm{~kg}$. The outer shell is thrown away, chopped, washed under running water, soaked in salt water, the aim is to reduce the level of calcium oxalate in taro which can cause itching when taking it, and drained, then put in an oven at 40-50 degrees Celsius to dry. After being dried, it is cleaned again from the dirt that is still attached, then weighed and pollinated using a blender until it becomes flour. Taro stem flour is sieved using 100 mesh after it is weighed and stored in a tightly closed container in a dry place [5]. 


\section{Glycemic Index of Taro Stem Flour (Colocasia esculenta) in Male White Rats}

\section{Determination of Water Content}

$1 \mathrm{~g}$ flour (low accuracy) or $5 \mathrm{~g}$ (moderate accuracy), flour is stored on the punch, flattened to cover the surface of the punch and then closed, and measured at $105^{\circ} \mathrm{C}$, until a beep sounds indicating that the process has finished. On the screen will be shown the percentage of water content of the sample tested automatically (done duplo). The simplicia water content in general is less than $10.5 \%$ [6].

\section{Determination of Ash Content}

Samples were weighed carefully $\pm 2 \mathrm{~g}$ which had been crushed, put into platinum or crucified silicate crucible. The crust is then slowly released in the furnace at a temperature of $700^{\circ} \mathrm{C}$ until ash occurs, cooled and weighed until a fixed weight or successive weighting difference cannot be more than $0.25 \%$. Ash content is calculated against the material that has been dried in the air [6].

\section{Phytochemical Test}

\section{- Alkaloid Test}

A total of $0.5 \mathrm{~g}$ of sample was added with $1 \mathrm{~mL}$ of $2 \mathrm{~N}$ $\mathrm{HCL}$ and $9 \mathrm{~mL}$ of aquadest, heated with water, removed and allowed to cool. The solution is filtered and the filtrate is taken. One drop of filtrate was reacted with $1 \mathrm{~mL}$ of Dragendorff reagents, Mayer reagents, and Bouchardat reagents. Positive results are indicated by the formation of white deposits on the addition of Dragendorff reagents and Bouchardat reagents [7].

\section{- Flavonoids test}

As much as $0.5 \mathrm{~g}$ were dissolved in $3 \mathrm{~mL}$ of methanol, 2-3 drops of ethanol, $\mathrm{Mg}$ powder and a few drops of $5 \mathrm{M}$ hydrochloric acid were added. red to purple violet arises indicating flavonoids. Flavonoid tests can also be done by replacing magnesium powder using zinc powder, a positive reaction shows a pink color [8].

\section{- Saponin test}

A total of $0.5 \mathrm{~g}$ of sample is added with $10 \mathrm{~mL}$ of hot water, will produce a stable foam after 1 minute by adding hydrochloric acid [8].

\section{- Tanin Test}

Tannin test is done by:

- A total of $0.5 \mathrm{~g}$ of sample is added with $10 \% \mathrm{NaCL}$ solution and $10 \%$ of gelatin is added, white precipitate will appear.

- A total of $0.5 \mathrm{~g}$ of sample was added with FeCL3 solution where tannins were shown by the formation of dark blue or greenish black [8].

\section{Carbohydrate Test}

- Moisture Content (same as above)

- Abu Content (same as above)

- Protein levels

Carefully weighed $1 \mathrm{~g}$ of sample was put into a kjeltec tube, added $2 \mathrm{~g}$ of selen mixture, $12 \mathrm{ml}$ of concentrated $\mathrm{H} 2 \mathrm{SO} 4$, then ignited digestion block, destroyed at $400^{\circ} \mathrm{C}$ for 1 hour, turned off digestion block, chilled. Then sequence sequences are made in kjeltec with AN300 program, then install the kjeltec tube and run the sequence, setting blank.
Protein levels $=\frac{(v 1-v 2) \times N \times 1,4007 \times C f}{W}$

\section{- Fat Levels (Hydrolysis or Weilbul methods)}

Carefully weighed 1-2 g, added $30 \mathrm{ml}$ of $25 \%$ HCL, $20 \mathrm{ml}$ of water and added a few boiling stones, then boil approximately 15 minutes, filtered while hot, wash with hot water until the acid does not react again, dried filter paper and its contents on the temperature is $100-150^{\circ} \mathrm{C}$, then put it into a wrapping filter paper, extracted with hexane for 2-3 hours, at a temperature of $\pm 80^{\circ} \mathrm{C}$, hexane is distilled and the fat extract is dried at a temperature of 100-150inginkanC, then cooled in an exator and weighed, drying is repeated until a fixed weight is obtained.

\section{- Calculation}

Carbohydrates $(\%)=100 \%-(\%$ Ash $+\%$ Water $+\%$ Protein $+\%$ Fat)

\section{Acclimatization}

The experimental animals used were 10 adult male white rats with good body health condition with an average body weight of 200-300 g. All experimental animals were fed pur as much as $10 \%$ of body weight. Weighing weight is carried out on day 0 and day 7. Drinking is not limited or ad libitum. Chaff replacement and cage washing are done once a week.

\section{Glycemic Index Measurement}

In the GI test 10 test animals were used with normal criteria, not suffering from diabetes. Test animals undergo full fasting (except water) during overnight. The next day, fasting blood glucose levels were measured. Furthermore, the test animals were given pure glucose (reference food) as much as $0.9 \mathrm{~g} / 200 \mathrm{~g}$ BB. For two hours of consumption of the test food, blood samples were taken every 30 minutes to measure their glucose content (measurement of 0, 30, 60, 90 and 120 minute glucose levels). After 3 days, the same thing is done by giving $0.9 \mathrm{~g} / 200 \mathrm{~g} \mathrm{BB}$ of taro stem flour (as a test food) to the test animals with the same glucose levels as above.

\section{Calculation of the Glycemic Index}

The calculation of the glycemic index (GI) is done to get a conclusion of the research results. According to Monro and Shaw (2008), the calculation of the food glycemic index can use the following formula:

GI $=\frac{\text { IAUC food }}{\text { IAUC glucose }} \times 100 \%$

\section{RESULTS AND DISCUSSION}

\section{A. Results of Determination and Making of Taro Stem Flour}

Taro stems (Colocasia esculenta) used in this study were obtained from the Bogor Main Market. Based on the results of plant identification conducted at the Indonesian Institute of Sciences (LIPI) Cibinong. Jalan raya Jakarta - Bogor KM. 46 Cibinong 16911 stated that the identity of the plant used in this study was taro with the Latingrame Colocasia esculenta from the Araceae tribe. The part of the in this study is the stem. 
Taro stem flour used in this study was made from $4 \mathrm{~kg}$ of fresh taro stalk waste, then dried and mashed up to obtain $135.3 \mathrm{~g}$ of taro stem flour with a yield percentage of $3.3825 \%$. Organoleptically, the resulting taro stems flour is smooth, brown in color, smells of milk, and has a slight taste.

\section{B. Characterization Results}

Examination of the quality characteristics carried out on taro stem flour include the determination of water content and the determination of ash content. The purpose of testing this parameter is to determine the quality of the test sample used as research material.

Determination of water content is carried out using a moisture balance tool. Based on the results of the study, it was obtained the value of the water content in btalas stem flour that was $7.37 \%$. The results obtained indicate that taro stems are declared eligible, because a material is considered safe enough if it has a water content of less than $10 \%$ [9].

Determination of ash content aims to determine the characteristics of residual levels of non-organic ash after ignorance. Taro stem flour is heated at high temperature so that the organic compounds and their derivatives are decomposed and evaporated. The results of the determination of ash content obtained from taro stem flour were 3, 23\%. The results obtained show that taro stems meet the requirements, because the ash content of simplicia in general is less than $5 \%$ [9]. The results of water content and ash content can be seen in Table 1 .

Table 1. Results of Determination of Moisture and Ash Content in Taro Stem Flour

\begin{tabular}{|c|c|}
\hline Taro Stem Flour & Average Percentage (\%) \\
\hline Water content & 7.37 \\
\hline Ash content & 3.23 \\
\hline
\end{tabular}

\section{Results of Identification of Phytochemical Compounds}

Phytochemical test is a qualitative test based on changes in color or formation of a sediment. Phytochemical test was carried out as a preliminary test of taro stem flour which aims to determine the class of secondary metabolites contained in the taro stem. The complete data can be seen in Table 2 .

Table 2. Results of Identification of Phytochemical Compounds

\begin{tabular}{|c|c|c|c|}
\hline $\begin{array}{c}\text { Group } \\
\text { Compound }\end{array}$ & Reagent type & Observation result & Explanation \\
\hline Flavonoids & Mg powder & Red to purple red & + \\
\hline \multirow{2}{*}{ Alkaloids } & Mayer & No changes & \multirow{2}{*}{-} \\
\cline { 2 - 3 } & Bouchardat & No changes & \\
\hline \multirow{2}{*}{ Tannin } & Gelatins and $\mathrm{NaCl}$ & White sediment & + \\
\cline { 2 - 3 } & $\mathrm{FeCl}_{3}$ & Dark blue & + \\
\hline Saponin & Water and $\mathrm{HCl}$ & Foam is not lost & + \\
\hline
\end{tabular}

Explanation : (+) sign shows positive results; the sign (-) shows a negative result.

Phytochemical test results on taro stem flour showed positive results obtained in the testing of flavonoids, tannins and saponins. Analysis of flavonoid compounds in taro stem flour showed a positive result which was marked by the formation of changes in the color of the sample to red to violet red. These color changes are in accordance with the parameters stated in [8].

Analysis of tannin compounds in taro starch showed positive results which were characterized by the formation of sediment when reacted with $10 \%$ gelatin and $10 \% \mathrm{NaCl}$. Tannin analysis was also carried out by adding $\mathrm{FeCl} 3$, from the results of the test formed a change in the color of the sample to dark blue or blackish green which showed that the btalas flour containing positive tannin.

\section{Carbohydrate Test Results}

Carbohydrates are a source of calories. The number of calories produced from $1 \mathrm{~g}$ carebohydrate is $4 \mathrm{kcal}$. Based on the results of the analysis, carbohydrate levels of taro starch with the method by difference can be seen in the following Table 3 .

Table 3. Carbohydrate Test Results

\begin{tabular}{|c|c|c|c|c|c|}
\hline No & Parameter & Unit & Result & LoD & Method \\
\hline 1 & Total Energy & $\begin{array}{c}\text { Kcal/100 } \\
\mathrm{g}\end{array}$ & $\begin{array}{c}292.3 \\
0\end{array}$ & - & Calculation \\
\hline 2 & $\begin{array}{c}\text { Total Energy } \\
\text { from Fat }\end{array}$ & $\begin{array}{c}\text { Kcal/100 } \\
\mathrm{g}\end{array}$ & 21.06 & - & Calculation \\
\hline 3 & $\begin{array}{c}\text { Moisture } \\
\text { Content }\end{array}$ & $\%$ & 10.94 & - & $\begin{array}{c}\text { SNI 01-2891-1992 } \\
\text { point 5.1 }\end{array}$ \\
\hline 4 & Ash Content & $\%$ & 18.91 & - & $\begin{array}{c}\text { SNI 01-2891-1992 } \\
\text { point 6.1 }\end{array}$ \\
\hline 5 & Total Fat & $\%$ & 2.34 & - & $\begin{array}{c}18-8-5 / \text { MU/SMM- } \\
\text { SIG, Weilbull }\end{array}$ \\
\hline 6 & Proteins & $\%$ & 12.16 & - & $\begin{array}{c}18-8-31 / \text { MU/SMM- } \\
\text { SIG, Kjeltec }\end{array}$ \\
\hline 7 & $\begin{array}{c}\text { Total } \\
\text { Carbohidrate }\end{array}$ & $\%$ & 55.65 & - & $\begin{array}{c}18-8-9 / \text { MU/SM } \\
\text { M- SIG }\end{array}$ \\
\hline
\end{tabular}

- Condition of Trying Animals After Acclimatization

The experimental animals used in this study were 10 male Sprague Dawley white rats with good health conditions with an average body weight of 200-300 g and 3-4 months old. The selection of experimental animals is done by taking into account the factors of age, body weight and gender to ensure uniformity or homogeneity in the research process.

- Calculation of Glycemic Index Value

Based on the results of blood glucose measurements carried out using a glucometer tool, it was obtained the experimental blood glucose response to the reference food (pure glucose) and can be seen in Table 4.

Table 4. Response of Blood Glucose to Pure Glucose

\begin{tabular}{ccccccc}
\hline \multirow{2}{*}{$\begin{array}{c}\text { Animal } \\
\text { test }\end{array}$} & \multicolumn{5}{c}{ Response of Blood Glucose to Pure Glucose } & \multirow{2}{*}{ AUC } \\
\cline { 2 - 5 }$(\mathrm{mg} / \mathrm{dL})$ & $0^{\circ}$ & $30^{\circ}$ & $60^{\circ}$ & $90^{\circ}$ & $120^{\circ}$ & \\
\hline 1 & 95 & 115 & 95 & 95 & 85 & 14850 \\
2 & 87 & 152 & 113 & 113 & 91 & 14010 \\
3 & 93 & 103 & 91 & 79 & 77 & 10740 \\
4 & 85 & 99 & 91 & 82 & 61 & 10350 \\
5 & 79 & 102 & 91 & 71 & 71 & 10155 \\
6 & 99 & 99 & 91 & 91 & 99 & 11400 \\
7 & 85 & 89 & 80 & 69 & 75 & 9540 \\
8 & 116 & 125 & 91 & 82 & 89 & 12015 \\
9 & 85 & 97 & 92 & 90 & 91 & 10995 \\
10 & 84 & 99 & 121 & 80 & 99 & 11760 \\
\hline Aver age & 90,8 & 108 & 95,7 & 85,2 & 83,8 & 11581,5 \\
\pm Dev & $\pm 10,67$ & $\pm 18,43$ & $\pm 12,02$ & $\pm 12,80$ & $\pm 12,47$ & \\
\hline
\end{tabular}

Giving pure glucose increases blood sugar levels at minute 0 which is $90.8 \mathrm{mg} /$ $\mathrm{dL}$ to $108 \mathrm{mg} / \mathrm{dL}$ at minute 


\section{Glycemic Index of Taro Stem Flour (Colocasia esculenta) in Male White Rats}

30 . The measurement results increase by $18.94 \%$. The results for animal blood glucose response to the provision of test food in the form of taro starch can be seen in Table 5 .

Table 5. Response of Blood Glucose to Taro Stem Flour

\begin{tabular}{ccccccc}
\hline \multirow{2}{*}{$\begin{array}{c}\text { Anim al } \\
\text { test }\end{array}$} & \multicolumn{5}{c}{ Response of Blood Glucose to Taro Stem Flour } & \multirow{2}{*}{ AUC } \\
\cline { 2 - 5 } & $0^{2}$ & $30^{\circ}$ & $60^{\circ}$ & $90^{\circ}$ & $120^{\circ}$ & \\
\hline 1 & 71 & 84 & 75 & 84 & 107 & 9960 \\
2 & 102 & 121 & 81 & 115 & 118 & 12810 \\
3 & 89 & 89 & 99 & 84 & 71 & 10560 \\
4 & 73 & 82 & 89 & 78 & 91 & 9930 \\
5 & 89 & 95 & 81 & 82 & 82 & 10305 \\
6 & 97 & 134 & 148 & 121 & 121 & 15360 \\
7 & 76 & 81 & 73 & 78 & 73 & 9195 \\
8 & 76 & 100 & 80 & 97 & 84 & 10710 \\
9 & 96 & 84 & 87 & 89 & 76 & 10380 \\
10 & 89 & 91 & 105 & 76 & 73 & 10590 \\
\hline Average & 85,8 & 96,1 & 91,8 & 90,4 & 89,6 & 10980 \\
\pm Dev & $\pm 11,04$ & $\pm 17,85$ & $\pm 22,17$ & $\pm 15,82$ & $\pm 19,05$ & \\
\hline
\end{tabular}

Administration of taro stem flour increased blood glucose levels at minute 0 , which was $85.8 \mathrm{mg} / \mathrm{dL}$ to $96.1 \mathrm{mg} / \mathrm{dL}$ at minute 30 . On the measurement results, it increased by $12 \%$. This value is the peak of the increase because in the next minute blood glucose levels decrease. Data from the results of blood glucose measurements in experimental animals against reference foods (pure glucose) and test foods (taro starch flour) were calculated by each AUC (area under the curve) of animal experiments with the formula:

$\mathrm{AUC}=1 / 2\left(\mathrm{c}_{1}+\mathrm{c}_{2}\right)\left(\mathrm{t}_{2}-\mathrm{t}_{1}\right)+1 / 2\left(\mathrm{c}_{2}+\mathrm{c}_{3}\right)\left(\mathrm{t}_{3}-\mathrm{t}_{2}\right)+1 / 2\left(\mathrm{c}_{3}\right.$ $\left.+\mathrm{c}_{4}\right)\left(\mathrm{t}_{4}-\mathrm{t}_{3}\right)+1 / 2\left(\mathrm{c}_{4}+\mathrm{c}_{5}\right)\left(\mathrm{t}_{5}-\mathrm{t}_{4}\right)$

The results of AUC from each experimental animal can be seen in Table 6

Table 6. AUC values Each Animals Test

\begin{tabular}{|c|c|c|}
\hline Animal Test & AUC Pure Glucose & AUC Taro Stem Flour \\
\hline 1 & 14850 & 9960 \\
\hline 2 & 14010 & 12810 \\
\hline 3 & 10740 & 10560 \\
\hline 4 & 10350 & 9930 \\
\hline 5 & 10155 & 10305 \\
\hline 6 & 11400 & 15360 \\
\hline 7 & 9540 & 9195 \\
\hline 8 & 12015 & 10710 \\
\hline 9 & 10995 & 10380 \\
\hline 10 & 11760 & 10590 \\
\hline Average & 11581,5 & 10980 \\
\hline
\end{tabular}

The AUC value of each experimental animal is then entered into the glycemic index formula. The glycemic index values of each experimental animal can be seen in Table 7.

Table 7. Glycemic Index Values Each Animals Test

\begin{tabular}{cc}
\hline Anim al Test & Glicemic Indeks (GI) \\
\hline 1 & 59,69 \\
2 & 81,37 \\
3 & 87,50 \\
4 & 85,38 \\
5 & 90,31 \\
6 & 119,91 \\
7 & 85,78 \\
8 & 79,33 \\
9 & 84,02 \\
10 & 80,14 \\
\hline Average & 85,343
\end{tabular}

According to Waspadji and Sukardji (2003), the glycemic index value is categorized into three groups, namely: low GI $(<55)$, medium GI (55-70), and high GI (> 70). Based on the table above, it can be seen that flour taro stems have a high glycemic index value of 85.343 which is obtained from the average glycemic index value of experimental animals. This is presumably because milling is done in the process of making taro stem flour and has a smaller particle size, the smaller the particle size, the greater the total surface area of food.

Rapid absorption results in hunger. Foods that are easily digested and absorbed can increase blood glucose levels quickly and this rapid increase in blood glucose levels forces the pancreas to secrete more insulin. High blood glucose levels also increase insulin response [1].

Factors that can influence the food glycemic index include processing (level of starch gelatinization and particle size), comparison of amylose with amylopectin, acidity and osmotic power, fiber content, fat and protein content, and food anti-nutrient levels.

Foods that have a high glycemic index value cause an increase in blood glucose levels quickly. Taro stem flour which has a high glycemic index value can be consumed by people or people who suffer from hypoglycemia and people who do not suffer from obesity, but the portion of taro starch meal must be considered because taro starch is a food that has a high glycemic index.

\section{CONCLUSION}

The results of the measurement of the glycemic index of taro starch using pure glucose reference food showed that taro stem flour had a glycemic index value of 85.343 and was included in the food category with a high glycemic index value $(>70)$.

Further research is needed on the measurement of the glycemic index of other processed foods made from taro corm flour (Colocasia esculenta). so that it can add to the list of foods that have a glycemic index value.It is necessary to test fiber content, fat content and protein, as well as the level of food nutrition.

\section{REFERENCES}

1. Rimbawan and A Siagiaan. Indeks Glikemik Pangan: Cara Mudah Memilih Pangan yang Menyehatkan. Jakarta: Penebar Swadaya, 2004

2. S. Waspadji and Sukardji. Pengkajian Status Gizi Studi Epidemiologi. Jakarta: Fakultas Kedokteran Universitas Indonesia, 2003.

3. _ 2005. Farmaceutical Care Untuk Penyakit Diabetes Mellitus.Departemen Kesehatan Republik Indonesia. Jakarta.

4. W. H. Self and C. D. Mcnaughton. Hypoglycemia. In (AdamJames G) Emergency Medicine Clinical Essential Second Ed. Elsevier Inc: 1379-1390, 2013.

5. DepKes RI. 1985. Cara Pembuatan Simplisia. Direktorat Pengawasan Obat dan Makanan. Jakarta.

$6 . \quad$ 2008. Farmakope Herbal Indonesia. Edisi I. Departemen Kesehatan Republik Indonesia. Jakarta.

$7 . \quad$ 1995. Material Medika Indonesia. Jilid VI. Direktorat Obat dan Makanan. Jakarta.

8. E. Hanani, Analisis Fitokimia. Jakarta: Penerbit Buku Kedokteran EGC. 2015.

9. 1989. Materia Medika Indonesia. Jilid III. Direktorat Obat dan Makanan. Jakarta. 